\title{
Clinical and Diagnostic Features in Three Dogs Naturally Infected with Borrelia spp.
}

\author{
Pavel Schánilec ${ }^{1}$, Kateřina Kybicová ${ }^{2}$, Carlos F. Agudelo ${ }^{1}$, František Treml ${ }^{3}$ \\ ${ }^{1}$ Small Animal Clinic, Faculty of Veterinary Medicine, University of Veterinary and Pharmaceutical Sciences \\ Brno, Czech Republic \\ ${ }^{2}$ National Institute of Public Health, National Reference Laboratory of Lyme Borreliosis, Prague, \\ Czech Republic \\ ${ }^{3}$ Department of Infectious Diseases and Veterinary Epidemiology, Faculty of Veterinary Medicine, \\ University of Veterinary and Pharmaceutical Sciences Brno, Czech Republic
}

Received March 30, 2009

Accepted December 3, 2009

\begin{abstract}
The aim of this study was to present clinical and neurological signs, laboratory abnormalities, serologic and/or molecular findings in three dogs from the region of Brno in the Czech Republic. All dogs were naturally infected with Borrelia burgdorferi sensu lato. The evidence of borrelial infection was proved by serial blood sampling for IgM and IgG anti-borrelial antibodies or plasma PCR. The dogs manifested corresponding clinical signs and one or more of the following criteria were fulfilled: (1) 4-fold or greater increase or decrease in B. burgdorferi s. 1. IgM or IgG antibodies serial titres in acute and convalescent stage of infection, (2) a shift from positive IgM to IgG antibodies titres, (3) decrease of $\operatorname{IgM}$ with concurrent increase of IgG antibodies in serial titres, (4) detection of borrelial DNA by PCR. Other possible tick-borne infections were excluded. All three dogs showed neurological signs (two of them meningoencephalomyelitis, one seizure connected with progressive renal disease). Their history, clinical signs, diagnostic procedures and treatment are described. Two of the dogs died and only one with meningoencephalomyelitis survived.

Our results show that borrelial infection must be taken into consideration, not only in cases with febrile and orthopaedic signs but also in many other clinical syndromes.
\end{abstract}

Borrelial infection, meningoencephalomyelitis, PCR, seizure, renal disease

Borreliosis is a zoonotic tick-borne disease caused by a Gram-negative spirochete Borrelia burgdorferi sensu lato (B. burgdorferi s.1.) which includes a complex of genospecies, three of which are considered to be pathogenic in dogs: $B$. burgdorferi sensu stricto $(B$. burgdorferi s. s.), Borrelia garinii (B. garinii) and Borrelia afzelii (B. afzelii) (Hovius et al. 1999a; Hovius 2005; Greene and Straubinger 2006). The main European vector is the tick Ixodes ricinus. Many species of mammals and birds were recognized as a reservoir of B. burgdorferi s. 1. (Gern et al. 1998; Hulinska et al. 2002; Piesman and Gern 2004). The clinical form of borreliosis occurs in humans, domestic animals, especially dogs, horses and cattle (Burges et al. 1987; Greene et al. 1991; Cohen et al. 1992; Skotarczak et al. 2005; Kybicová et al. 2009).

The close contact between dogs and humans, the common environment and the fact that borreliosis is emerging even in cities can be considered as indicators for outbreak detection (Štefančíková et al. 1998; Goossens et al. 2001). Clinical signs depend on the individual host response and vary widely, developing in relatively few individuals (Levy and Dreesen 1992; Levy and Magnarelli 1992). Both in humans and dogs, the condition can cause dermatological, musculoskeletal, neurological, renal and cardiovascular signs (Greene et al. 1991; Azuma et al. 1993; Straubinger et al. 1997; Straubinger 2000; Straubinger et al. 2000; Skotarczak and Wodecka 2003; Skotarczak et al. 2005; Greene and Straubinger 2006).

Address for correspondence:

Pavel Schánilec

Small Animal Clinic

University of Veterinary and Pharmaceutical Sciences Brno

Palackého 1/3, 61242 Brno, Czech Republic 
The diagnosis is based on a combination of several factors: epidemiology-epizootiological information, clinical signs, serological tests and PCR (Straubinger 2000; Straubinger et al. 2000; Skotarczak and Wodecka 2003; Skotarczak et al. 2005; Pejchalova et al. 2006; Kybicova et al. 2009). The seroprevalence for B. burgdorferi s. 1. in dogs was assessed in many European countries, e.g. in Slovakia ( ̌́tefančíková et al. 1998), Poland (Skotarczak et al. 2005), and Sweden (Egenvall et al. 2000). Specific antibodies to $B$. burgdorferi s. 1 . were detected in $6.5 \%$ of the population in the Czech Republic and the seroprevalence ranged between $0.0 \%$ and $28.6 \%$ (Pejchalová et al. 2006). In a recent study also in the Czech Republic the seropositivity of ELISA in IgM and IgG was $2.4 \%$ and $10.3 \%$, respectively (Kybicová et al. 2009).

In the Czech Republic DNA of B. garinii was detected in a blood sample of a dog only in one case (Kybicová et al. 2009).

The aim of this work is to present three cases of dog patients with a variety of clinical signs and positive detection of borrelial infection by serological tests or PCR.

\section{Materials and Methods}

All patients were presented to the emergency service of the Small Animal Clinic of the University of Veterinary and Pharmaceutical Sciences Brno and hospitalized there. All dogs were regularly vaccinated with polyvalent vaccines and dewormed but none of them was vaccinated against borreliosis. All dogs suffered from severe tick infestation and all dogs came from Brno/South Moravia, an endemic area of tick-borne encephalitis and borreliosis (Klimeš et al. 2001; Pejchalova et al. 2006).

Laboratory criteria for assessment of borrelial diagnosis

Patients were diagnosed with borrelial infection if they manifested corresponding clinical signs and one or more of the following criteria were fulfilled: (1) 4 -fold or greater increase or decrease in B. burgdorferi s. 1. IgM or IgG antibodies serial titres in acute and convalescent stage of infection, (2) a shift from positive IgM to IgG antibodies titres, (3) decrease of IgM with concurrent increase of IgG antibodies in serial titres, (4) detection of borrelial DNA by PCR.

CSF examination, haematology and serum biochemistry

Complete CSF analysis was made within 30 min from collection (Bagley 2003; Bagley and Bohn 2003; Bohn and Bagley 2003). Cell counts were performed using the Fuchs-Rosenthal counting chamber. Blood and cerebrospinal fluid (CSF) smears were stained with Hemacolor (Merck KGaA, Darmstadt, Germany). Routine haematological examination and selected biochemical values was performed.

Serology and PCR

The sera were examined by the enzyme immunoassay (EIA) for detection of borrelial IgG and IgM antibodies (TEST-LINE, Brno, Czech Republic), by EIA for the detection of tick-borne encephalitis virus (TBEV) Ig antibodies (TEST-LINE, Brno, Czech Republic) and by A. phagocytophilum immunofluorescence (IFA) canine IgG antibody test (Fuller Laboratories, Fullerton, CA, USA), all according to manufacturer's instructions. Levels of index positivity of antiborrelial antibodies: $<0.85$ negative, $0.85-1.15$ dubious, $>1.15$ positive.

The DNA samples were isolated from blood and CSF and were analyzed by standard PCR (Kybicová et al. 2009). Positive DNA samples were retested by restriction fragment length polymorphism (RFLP) analysis with 5S ( $r r f A)-23 \mathrm{~S}(r r l B)$ rDNA intergenic spacer primers (Derdáková et al. 2003) as in Kybicová et al. (2008).

\section{Case studies}

Case 1 (5-7/ 2002)

A five-month-old dog, $13 \mathrm{~kg}$, intact male Nova Scotia Duck Tolling Retriever was presented with a 2-week history of inability to move, general hyperesthesia and spasticity of the muscles of the head and neck. The previous veterinarian collected blood samples (day -14) for borreliosis (see Table 2) because he found the dog pyretic (3 previous days) and treated him with high doses of co-amoxicillin (30 mg. $\mathrm{kg}^{-1}$ PO BID) and non-steroidal drugs. The condition of the dog improved over the next 3 days. A week later, the dog started refusing to lie down; showing kyphosis, often remaining in a sitting position, being unable to make head and neck ventroflexion. At admission (day 0 ), the dog showed generalized hyperesthesia including vocalization and inability to move. The mental status alternated from depression and stupor to hysteria, accompanied by episodes of opisthotonus and myoclonia of both forelimbs. The cervical muscles were hypertonic and strong pain was elicited with mild manipulation of the neck. Examination of cranial nerves revealed moderate decreased trigeminal (CN V) sensation and facial (CN VII) reactivity on the left side with absence of reactions for the same nerves on the right side. Spinal reflexes showed hyperreflexia in all of four limbs. The dog remained preferentially in right lateral recumbency. CBC (Table 1) and antinuclear antibody test (ANA test) were sampled. Standard fluid support and treatment with co-amoxicillin $\left(25 \mathrm{mg} \cdot \mathrm{kg}^{-1}\right.$ IV TID) was given, together with Diazepam (single dose $1.5 \mathrm{mg} \cdot \mathrm{kg}^{-1}$ IV slowly) followed by phenobarbital (2 $\mathrm{mg} \cdot \mathrm{kg}^{-1}$ IV BID -TID) to control mental status. 
During the first two days of hospitalization the neurological status worsened, including spastic tetraparesis, tonic seizures with mild manipulation and permanent posture in right lateral recumbency. Reactivity of cranial nerves changed: CN V and CN VII function changed to hyperreactivity on the left side with severe hyporeflexia on the right side. Furthermore, direct and indirect pupilary reflexes were decreased on the right side while normal on the left. Additional findings included severe hyperesthesia in the orbital and cervical areas and bilateral blepharospasm. A multifocal lesion involving meninges, cortex, brainstem and cervical spinal cord was suspected and collection and examination of CSF was indicated. CSF analysis showed Pandy reaction (++) and white blood cell count of 40 cells $\cdot \mu 1^{-1}$. Cytology showed $60 \%$ of small lymphocytes, $13 \%$ of activated lymphocytes, $13 \%$ of monocytes, $13 \%$ activated monocytes up to macrophages and sporadically polymorphonuclears (PMN). Biochemistry showed proteinorhachia (TP $\left.0.81 \mathrm{~g} \cdot \mathrm{l}^{-1}\right)$. The glucose level was normal $\left(4.17 \mathrm{mmol} \cdot \mathrm{l}^{-1}\right)$. Aerobic and anaerobic cultures of CSF were negative. These findings were compatible with lymphocytic meningoencephalitis suggesting an infective aetiology.

The clinical and neurological status slowly improved during the following 4 days. On day 6 , the patient revealed mild disorientation, generalized symmetrical ataxia with hyperreflexia of all four limbs, lower neck and head position with moderate cervical discomfort. The general hyperesthesia and the pupilar and ocular changes persisted. The dog was able to eat and drink. Blood was sampled for TBE (negative) and borreliosis (Table 2). The dog was discharged and owners were instructed to provide nursing care. Treatment continued with co-amoxicillin ( $25 \mathrm{mg} \cdot \mathrm{kg}^{-1}$ PO BID) for the following 14 days and a dose of phenobarbital tapered for the following 3 days.

A week later the patient's condition gradually worsened (lethargy, anorexia and hyperthesia) and the owner by own initiative gave him prednisone $\left(1 \mathrm{mg} \cdot \mathrm{kg}^{-1} \mathrm{PO}\right.$ for three days) and by day 21 brought the dog to our clinic. The dog was lethargic, febrile $\left(40.3^{\circ} \mathrm{C}\right)$, tachycardic $\left(150\right.$ beats $\left.\cdot \mathrm{min}^{-1}\right)$, severely hyperesthetic with vision deficits on the right. The owner declined hospitalization. Treatment was changed to azithromycin ( $20 \mathrm{mg} \cdot \mathrm{kg}^{-1} \mathrm{PO}$ SID). From day 25 , the antibiotic was substituted with cefotaximum ( $85 \mathrm{mg} \cdot \mathrm{kg}^{-1}$ IV TID). Serum samples were submitted for antiborrelial

Table 1. Haematology and biochemistry results

\begin{tabular}{|c|c|c|c|c|c|c|c|}
\hline Indicator & Reference range / units & $\begin{array}{l}\text { Case } 1 \\
\text { day } 1\end{array}$ & $\begin{array}{l}\text { Case } 1 \\
\text { day } 38\end{array}$ & $\begin{array}{l}\text { Case } 2 \\
\text { day } 0\end{array}$ & $\begin{array}{l}\text { Case } 2 \\
\text { day } 44\end{array}$ & $\begin{array}{l}\text { Case } 3 \\
\text { day } 1\end{array}$ & $\begin{array}{l}\text { Case } 3 \\
\text { day } 10\end{array}$ \\
\hline ERY & $5.5-8.5 / 10^{12} \cdot 1^{-1}$ & 4.08 & 3.61 & 4.5 & 4.71 & 5.18 & 5.68 \\
\hline HB & $120-180 / \mathrm{g} \cdot \mathrm{l}^{-1}$ & 100 & 83 & 107 & 119 & 115 & 124 \\
\hline HT & $0.37-0.55 / 1 \cdot 1^{-1}$ & 0.28 & 0.24 & 0.33 & 0.34 & 0.35 & 0.39 \\
\hline TRC & $200-500 / 10^{9} \cdot 1^{-1}$ & 232 & 186 & - & - & 227 & 365 \\
\hline LEU & $6-17 / 10^{9} \cdot 1^{-1}$ & 36.2 & 23.9 & 8.6 & 9.6 & 8.7 & 7.1 \\
\hline Bands & $0-1 / 10^{9} \cdot 1^{-1}$ & 1.09 & 1.43 & 0.34 & 0.1 & 0.17 & 0 \\
\hline PMN & $3-11.4 / 10^{9} \cdot 1^{-1}$ & 31.8 & 19.8 & 5.59 & 7.68 & 5.48 & 2.13 \\
\hline LY & $1-4.8 / 10^{9} \cdot 1^{-1}$ & 2.53 & 2.39 & 2.15 & 0.58 & 2.09 & 4.12 \\
\hline MONO & $0-1.3 / 10^{9} \cdot 1^{-1}$ & 0.36 & 0.24 & 0 & 0 & 0.78 & 0.71 \\
\hline EO & $0-0.75 / 10^{9} \cdot 1^{-1}$ & 0.6 & 3.61 & 0.52 & 0.1 & 0.17 & 0.14 \\
\hline TP & $55-75 / \mathrm{g} \cdot \mathrm{l}^{-1}$ & - & 51.2 & 67.8 & 57.7 & 63.1 & - \\
\hline ALB & $23-34 / \mathrm{g} \cdot \mathrm{l}^{-1}$ & - & 21.6 & 30 & 28 & 30.7 & - \\
\hline GLO & $30-47 / g \cdot 1^{-1}$ & - & 29.6 & 37.8 & 29.7 & 32.4 & - \\
\hline $\mathrm{A} / \mathrm{G}$ & $0.7-1.1$ & - & 0.72 & 0.79 & 0.94 & 0.95 & - \\
\hline TB & $0-7 / \mu \mathrm{mol} \cdot 1^{-1}$ & - & 5.6 & - & 1.8 & - & - \\
\hline CRE & $30-120 / \mu \mathrm{mol} \cdot 1^{-1}$ & - & 118.6 & 503 & 859.1 & 65.0 & - \\
\hline $\mathrm{U}$ & $2.5-7 / \mathrm{mmol} \cdot 1^{-1}$ & - & 9.18 & 39.8 & 82.4 & 3.37 & - \\
\hline GLU & $3.3-7 \mathrm{mmol} \cdot \mathrm{l}^{-1}$ & - & 5.17 & 4.85 & 8.04 & NT & - \\
\hline ALP & $0.1-1.5 / \mu \mathrm{kat} \cdot \mathrm{l}^{-1}$ & - & 3.14 & 0.3 & 0.5 & 0.60 & - \\
\hline ALT & $\leq 1 / \mu \mathrm{kat} \cdot \mathrm{l}^{-1}$ & - & 2.4 & 1.6 & 2.3 & 0.74 & - \\
\hline $\mathrm{Ca}$ & $2-3 / \mathrm{mmol}^{\prime} \mathrm{l}^{-1}$ & - & 2.5 & 1.64 & 1.31 & 2.14 & - \\
\hline $\mathrm{P}$ & $0.9-2.5 / \mathrm{mmol}^{-1} \mathrm{l}^{-1}$ & - & 2.01 & 3.36 & 5.04 & 1.6 & - \\
\hline $\mathrm{Na}$ & $135-155 / \mathrm{mmol}^{-1} \mathrm{l}^{-1}$ & - & 151 & 152 & 145 & 143.0 & - \\
\hline $\mathrm{K}$ & $3.6-5.6 / \mathrm{mmol}^{-1} 1^{-1}$ & - & 5.3 & 5.39 & 5.28 & 4.24 & - \\
\hline
\end{tabular}

ERY - erythrocytes, HB - haemoglobin, HT - haematocrit, TRC - thrombocytes, LEU - leukocyte count, PMN - polymorphonuclears, LY - lymphocytes, MONO - monocytes, EO - eosinophils, TP - total proteins, ALB - albumin, GLO - globulin, TB - total bilirubin, CRE - creatinine, U - urea, GLU - glucose, ALP - alkaline phosphatase, ALT - alanine aminotransferase, $\mathrm{Ca}$ - calcium, $\mathrm{P}$ - phosphorus, $\mathrm{Na}$ - sodium, $\mathrm{K}$ - potassium 
Table 2. Results of the serological examination for Borrelia sp. (Case1)

\begin{tabular}{|l|l|l|l|l|l|}
\hline $\begin{array}{l}\text { Index of } \\
\text { positivity }\end{array}$ & Day -14 & Day 6 & Day 25 & Day 34 & Day 38 \\
\hline IgM (result) & $0.34(-)$ & $\mathbf{1 . 5 4}(+)$ & $\mathbf{2 . 2 6 ( + )}$ & $\mathbf{2 . 2 0}(+)$ & $\mathbf{3 . 8 7}(+)$ \\
\hline IgG (result) & $0.14(-)$ & $0.17(-)$ & $0.27(-)$ & $0.31(-)$ & $0.70(-)$ \\
\hline
\end{tabular}
day the patient's condition deteriorated and the owners requested euthanasia.

Post mortem CSF analysis showed Pandy reaction $(++)$ and white blood cell count of 110 cells $\cdot \mu \mathrm{l}^{-1}$. Cytology showed $25 \%$ of small lymphocytes, $43 \%$ of activated lymphocytes up to plasma cells, $21 \%$ of PMN, $11 \%$ monocytes up to macrophages. CSF biochemistry showed proteinorhachia $\left(0.97 \mathrm{~g} \cdot \mathrm{l}^{-1}\right)$ and decreased glycorhachia $\left(1.95 \mathrm{mmol} \cdot \mathrm{l}^{-1}\right.$, reference range: $\left.2.7-4.2 \mathrm{mmol} \cdot \mathrm{l}^{-1}\right)$. Cultures and borrelial PCR were also negative.

At necropsy, macroscopically the thickening of dura mater was found on the left cerebral hemisphere and multifocally through the spinal cord. Histopathology showed chronic meningoencephalomyelitis. Multiple malatic lesions were seen in the brain and spinal cord with atrophy of ventral spinal horns and their corresponding spinal roots. Additional findings were acute hepatitis, chronic diffuse granulomatous and necrotic myocarditis.

\section{Case 2 (7-9/2003)}

A five-year-old, $34 \mathrm{~kg}$, intact male Labrador Retriever was evaluated due to a history of two days of generalized short episodes of tonic-clonic seizures with unconsciousness. Initial clinical examination (day 0) showed mild lethargy and slight generalized ataxia. CBC and biochemistry were taken (Table 1). Serology for borreliosis was positive (IgM 2.32 - positive; IgG 0.94 - dubious). The next day the dog was hospitalized. Ultrasound examination showed bilateral hyperechogenity of the kidneys suggesting renal disease (RD), glomerulonephritis (GN) or pyelonephritis (PN). Urine was collected by cystocentesis and showed alkaliuria, hyperstenuria, cylindruria (granular casts), crystalluria (ammonium urate 1/field), also occasional bacteriuria and mild proteinuria $(+)$ were found. Urinary protein/creatinine ratio (Up/Uc ratio) was 3.6 (normal range: $\leq 1)$. The dog was treated initially with saline $0.9 \%$. TBE, anaplasmosis and leptospirosis (L. icterohaemorrhagiae and L. grippotyphosa) serologies were negative. On day 4, the owner declined further hospitalization. The patient was discharged with doxycycline (10 mg $\mathrm{kg}^{-1}$ PO BID) initially for one week. The owner missed the recommended follow-ups and came on day 44. According to his report the dog was doing better excepting for mild exercise intolerance. CBC and biochemistry were checked (Table 1). Borrelial antibodies were measured (IgM 1.47 - positive; IgG 3.52 - positive). The owner did not return for the next follow-ups and by telephonic communication after 2 months he reported that the dog had died.

\section{Case 3 (4/2006 - 8/2007)}

An eight-year-old, $40 \mathrm{~kg}$, intact male Labrador Retriever was referred with a 1-day history of reluctance to move and progressive ataxia, which worsened to tetraparesis (day 0). The last 2 weeks the dog was being treated for a phlegmon on the right forelimb by the referring veterinarian a received unknown antibiotic treatment for one week. One day before admission he started treating him with marbofloxacin. At admission (day 1) the dog seemed to be in good body condition, he had hyperaemic mucous membranes, hot spot in the neck area lasting for 4 days, mild antebrachial oedema on the right forelimb, enlargement of the left axillar lymph node and bradycardia $\left(60\right.$ beats $\left.\cdot \mathrm{min}^{-1}\right)$. Neurologically, the patient was depressed, tetraparetic with a lateralized generalized ataxia to the right, pleurothotonus to the right, and also showed signs of cervical discomfort especially with ventroflexion of the head. Although the dog fell down to the right, he was able to walk a few steps without help. Examination of cranial nerves showed diffuse hypersensitivity in the facial areas. The spinal reflexes were normal to increased. $\mathrm{CBC}$ and biochemistry were taken (Table 1).

An electrocardiography $(\mathrm{ECG})$ revealed bradycardia, $1^{\text {st }}$ degree atrioventricular block and prolonged QT interval.

CSF evaluation revealed Pandy reaction (++), and white blood cell count of 99 cells $\cdot \mu 1^{-1}$. Cytology showed $70 \%$ of small lymphocytes, $9 \%$ of middle lymphocytes up to plasmocytes, $20 \%$ of MONO and $1 \%$ PMN. Biochemistry showed proteinorhachia $\left(1.32 \mathrm{~g} \cdot \mathrm{l}^{-1}\right)$ and normal glucose value $\left(3.3 \mathrm{mmol} \cdot \mathrm{l}^{-1}\right)$. Aerobic and anaerobic cultures and borrelial PCR of CSF were negative.

Phenobarbital (2-4 mg. $\mathrm{kg}^{-1}$ IV TID and then BID) was administered and the treatment with marbofloxacin ( $2 \mathrm{mg} \cdot \mathrm{kg}^{-1}$ IV BID) was continued. Standard fluid support was given.

On day 2, ANA test, Borrelia, Anaplasma and TBE serology were negative, however, the PCR from blood for borrelial DNA was positive (Plate XXII, Fig. 1, Table 3).

On day 3, the neurological status worsened almost to stupor and the cervical discomfort increased; there were also hypomotility of the tongue, severe blepharospasmus on the right side and intermittent neck myoclonus. Mannitol was added to the therapy $\left(1 \mathrm{~g} \cdot \mathrm{kg}^{-1}\right.$ during $20 \mathrm{~min}$, single dose $)$. On day 4, the dog started to eat small amounts of meal but showed intention tremor and dysmetria of the head and neck, also he was able to alternate recumbency. From day 6, the dog was able to stand up and take a few steps with support. Marbofloxacin was changed to enrofloxacin (5 mg. $\mathrm{kg}^{-1} \mathrm{SC}$ BID). On day 10, CBC, biochemistry (Table 1), and Borrelia serology (Table 3) were 
Table 3. Results of the serological examination for Borrelia sp. (Case 3)

\begin{tabular}{|l|l|l|l|l|}
\hline Index of positivity & Day 2 & Day 10 & Day 33 & \multicolumn{1}{|c|}{ Day 422 } \\
\hline IgM (result) & $0.5(-)$ & $0.634(-)$ & $\mathbf{1 . 0 4 4}(+/-)$ & $0.517(-)$ \\
\hline IgG (result) & $0.3(-)$ & $0.562(-)$ & $0.716(-)$ & $0.869(+/-)$ \\
\hline PCR & B.g. (+) & negative & negative & negative \\
\hline
\end{tabular}
(he owners complained about a 4-mo history of faecal and urinary incontinence. Neurologic evaluation revealed symptoms corresponding with the syndrome of cauda equina. Lumbar X-rays were normal. Borrelial serology and PCR were negative.

\section{Results and Discussion}

All presented cases showed historical, clinical and diagnostic findings that strongly indicated borrelial infection.

In all dogs the clinical signs started between April and July. It correlates with the seasonal activities of ticks and dogs (Hovius et al. 1999b; Hovius et al. 1999c; Steere 2001; Bhide et al. 2004; Pejchalová et al. 2006; Kybicová et al. 2009).

Clinical illness in infected dogs occurs 2 to 6 months after tick exposure. In humans as well as animals the clinical symptoms are divided into three stages. Stage I (early localized infection) can be presented in humans as erythema migrans. This stage is not seen in dogs. Stage II (early disseminated infection) can affect all organ systems, and can manifest itself by musculoskeletal pains, variable neurological symptoms, cardiovascular and renal symptoms. During this stage we can often see clinical symptoms and detect antibody dynamics. A general malaise often precedes or combines with a lameness episode and can be accompanied with moderate to high fever, anorexia and listlessness. Stage III (late persistent infection) can cause chronic symptoms, recurrent arthritis and chronic neurological disorders (Baranton 2002; Hovius 2002; Higgins 2004; Hovius 2005; Greene and Straubinger 2006).

Diagnosis of borreliosis is obtained by the presence or absence of the following factors: 1) the presence of typical clinical symptoms; 2) exclusion of differential diagnosis; 3) apparent reaction to antibiotic; 4) evident contact with a tick or living in an endemic area; 5) the presence of antibodies in the blood serum. The latter criterion has been a serious diagnostic indication, however, seropositivity determined from a single sample cannot differentiate between past and present exposure, and cannot on its own constitute a basis for diagnosis of an active infection (Egenvall et al. 2001; Bhide et al. 2004; Skotarczak et al. 2005).

ELISA is considered to be sufficiently specific to be used separately for determining the dynamics of the antibody response to B. burgdorferi s.l. and can react in early stage of illness (Hovius et al. 1999b).

The timing of serologic examination is important in determination whether active or past infection is responsible for seropositivity. Early serodiagnostic results are usually negative because the immune response to Borreliae develops gradually. Antiborrelial antibodies IgM are produced 1 to 2 weeks after infection (Hovius et al. 1999b), correlate with the onset of clinical illness, and remain elevated for 2 months (Greene and Straubinger 2006). IgG-ELISA positive titres develop within 4 to 6 weeks (Appel et al. 1993), culminate at 3 months and last 1 to 2 years after exposure (Straubinger et al. 2000; Goossens et al. 2001). Simultaneous measurements of IgG and IgM and paired-sample titres are recommended for detection of borrelial infection. False-negative antibody test results are rare (Greene and Straubinger 2006) so clinical syndromes together with PCR and serial serology indicate a very likely borrelia-induced disease.

Clinical and laboratory findings of borrelial infection are described in more detail for each of the cases due to the particular variations between subjects: 
In Case 1, the proof of infection with Borrelia spp. was based on an increase of more than 10 -fold in IgM antibodies in 52 days (Table 2). IgM increased from negative up to high positive titres. IgG was always negative. Titres of antiborrelial antibodies were examined five times.

In Case 2, antiborrelial antibodies were examined only twice, on day 0 and 44 . A shift from IgM to IgG with a decrease in IgM was detected.

In Case 3, the proof of presence of borrelial infection was based on positive PCR sera (B. garinii) and clinical, neurological, CSF and ECG findings. Sera testing for antiborrelial antibodies (four times) showed only a weak response at day $33^{\text {rd }}$ (Table 3 ). Since the dog was treated two weeks before presentation, probably with antibiotics that affected Borreliae, it is possible that his immune response was delayed or reduced. The later PCR detection could be explained by insufficient initial antibiotic treatment (dose, duration), repetitive proliferation of the surviving spirochetes or re-infection (Straubinger et al. 1997).

The immune response and PCR findings suggested that all three cases showed signs of early disseminated stage of borrelial infection.

Variable neurological signs are described in dogs (Azuma et al. 1993; Azuma et al. 1994; Baranton 2002; Hovius 2002; Higgins 2004; Hovius 2005; Greene and Straubinger 2006).

Both dogs with meningoencephalomyelitis (Cases 1, 3) were CSF evaluated and the findings corresponded to a suspected central nervous system (CNS) inflammation because of proteincytological association. Serial sampling ofCSF in Case 1 showed increased activation of mononuclear cells, especially lymphocytes, their increased number and no signs of other bacterial presence.

CSF findings are not pathognomic only for borrelial infection (Adam 1999). For both dogs the PCR of CSF was negative. It corresponds with other findings by many authors because Borreliae are very easily eliminated by the immune system and/or by penetrating antibiotics. Different results are described in the literature concerning the culture and PCR detection Borreliae in the nervous system (Appel et al. 1993; Hovius et al. 1999c; Chang et al. 2001; Straubinger 2000). Histological findings in Case 1 correspond with neurological and CSF findings.

In Case 2, neurological signs were reported. The origin of seizures remained unclear. They can be part of nephro-encephalopathy, because azotaemia or CNS borrelial infection cause irritation (Azuma et al. 1993; Azuma et al. 1994). Interestingly, Chang et al. (2001) described that experimentally infected dogs developed mild focal meningitis, encephalitis, and perineuritis but without neurological signs. These symptoms in Case 2 could probably have been caused by silent borrelial CNS infection with a transient relapse. The progressive renal failure, the moderate to severe azotemia and the marked proteinuria were detected along with IgM/IgG shift (Grauer et al. 1988; Greene and Straubinger 2006; Gerber et al. 2007). A possible predisposition of Labrador and Golden Retrievers to renal involvement has been described. The same authors claim that the duration of clinical renal illness is $24 \mathrm{~h}$ to 8 weeks (Greene and Straubinger 2006).

We deduce from the ECG changes and post mortem findings in Cases 1 and 3 that the incidence of cardiac manifestations in borreliosis could be higher than previously thought. Humans have a cardiac involvement in Lyme disease in $8-10 \%$ of adults (Nagi et al. 1996; Bateman and Sigal 2000; Nalmas et al. 2007). The natural incidence of Lyme carditis in veterinary medicine has not been yet estimated. The observed cardiovascular syndromes include the presence of arrhythmia (variable degrees of atrioventricular block, supraventricular and ventricular arrhythmia Levy and Duray 1988; Nalmas et al. 2007), myocarditis, pericarditis, dilated cardiomyopathy and coronary artery disease (Gasser et al. 1999). Generally, a positive Lyme titre and accompanying cardiac signs are present which was demonstrated in our patients. The overall prognosis of Lyme carditis is good, although recovery may be delayed and later the progressive effects of inflammation and 
toxins can cause heart failure (Nagi et al. 1996; Gasser et al. 1999; Cepelova 2008). The chronic diffuse granulomatous and necrotic myocarditis found in Case 1 could suggest the cystic form of the disease (Giudice et al. 2003).

CBC revealed persistent mild hypochromic anaemia in two cases (Case 1,2) and borderline anaemia in the Case 3. Our findings are similar to those mentioned e.g. by Breitschwerdt et al. 1994, however, the majority of authors did not record any specific CBC changes (Greene and Straubinger 2006). Anaemia can be caused in an acute stage of bacteraemia or inflammation because of bone marrow suppression or due to direct penetration of B.burgdorferi s.l. to the bone marrow. PCR findings of Borreliae in the bone marrow were described by Hovius et al. (1999c). In Case 1, anaemia could have occurred because the dog was young and fast growing. Moderate leukocytosis observed in Case 1 is a nonspecific sign of inflammation; it is not possible to rule out a concurrent disease that may explain this finding.

The moderate panhypoproteinaemia in Case 1 and elevated ALT (Cases 1,2) can be a nonspecific effect of the systemic inflammation. It could be caused by fasting, but also can be suggested as a consequence of acute hepatitis caused by Borreliae or concurrent disease. In one case acute hepatitis was verified by necropsy. The higher prevalence of Borrelia in liver samples in symptomatic dogs is also described (Hovius et al. 1999c; Greene and Straubinger 2006). Elevated ALP in the Case 1 could be caused by the same reason but also very probably was caused by the fast growth of bones. The moderate to severe azotaemia, hyperphosphataemia and hypocalcaemia in Case 2 are signs of progressive renal disease and were already described above.

Commonly, concurrent tick-borne diseases can occur in infested animals (Egenvall et al. 2000; Klimeš et al. 2001; Higgins 2004; Kybicová et al. 2009). Sera of all three dogs were evaluated for borreliosis (see above), TBE and anaplasmosis with negative results, thus ruling out this possibility. The dog with signs of RD (Case 2) was also negative for leptospirosis.

Two dogs (Cases 1, 3) were also tested for ANA antibodies with a negative result. Lupus erythematosus is a disease that can cause a lot of clinical signs (including neurological) and the test should be done as a routine in patients showing systemic or organ inflammatory diseases.

Ceftriaxone, cefotaxime, azithromycin, amoxicilin and doxycycline are thought as the most effective antimicrobial drugs against Borrelia when administered at an early clinical stage of infection. In Case 1, co-amoxicilin, azithromycin and cefotaxime were administered, but the use of corticosteroids could have been a trigger for reactivation of a poorly controlled infection. The penetration of antibiotics to CNS also depends on the integrity of blood-brain barrier. It is probable that co-amoxicilin could be less effective in CNS. In Case 2, the owner aborted the administration of doxycycline, which might therefore not have been sufficiently effective. Quinolones are ineffective in treating borreliosis. They were used in Case 3 because the results of PCR were known too late (a month after sampling) and the owner declined further therapy.

We suggest that supportive complementary nursing care and cage rest of patients are among the mainstays of the complex therapy of encephalitis. As showed in Case 3, it could be important for surviving despite the wrong antibiotic treatment. Duration of cage rest depends on the severity of the illness. In Cases 1 and 2, the owner finished hospitalization prematurely and the patients did not get adequate rest.

\section{Klinické příznaky a diagnostické postupy u tř́i psů přirozeně infikovaných Borrelia spp.}

Cílem studie je popsat klinické a neurologické př́znaky, laboratorní, sérologické a/nebo molekulární nálezy u tří psů z okolí Brna (Česká republika). Všichni psi byli přirozeně infikováni Borrelia burgdorferi sensu lato a infekce byla potvrzena opakovaným vyšetřením IgM a IgG 
boreliových protilátek nebo pomocí PCR. Psi s klinickými příznaky splňovali jedno nebo více z následných kriterií: (1) čtyřnásobné nebo vyšší zvýšení nebo snížení titrů IgM nebo IgG protilátek proti $B$. burgdorferi $\mathrm{s}$. 1. při opakovaných vyšetřeních v akutní nebo rekonvalescentní fázi infekce, (2) změna z pozitivních IgM do pozitivních IgG titrů, (3) současné snížení IgM a zvýšení IgG protilátek, (4) nález boreliové DNA metodou PCR. Další možné infekce přenášeny klíšt’aty byly vyloučeny. Všichni tři psi vykazovali neurologické př́znaky (dva meningoencefalitidu a jeden křeče spojené s progresivním onemocněním ledvin). Je popsána anamnéza, klinické př́iznaky, diagnostické postupy a jejich léčba. Dva z pacientů uhynuli a jeden pacient s meningoencefalitidou přežil. Tento článek ukazuje, že boreliová infekce musí být zvažována i v př́padech jiných příznaků než jsou febrilní stavy a ortopedické př́znaky.

\section{Acknowledgements}

The authors thank V. Válková and J. Kybic for reviewing the manuscript.

\section{References}

Adam P 1999: Likvorologie. In: Duniewicz M a kol. (Eds): Neuroinfekce. Maxdorf, Praha: pp. $21-85$

Appel MJG, Allan S, Jacobson RH, Lauderdale T, Chang Y, Shin S, Thormford S, Todhunter R and Summers B 1993: Experimental Lyme diseases in dogs produces arthritis and persistent infection. J Infect Dis 167: 651-654

Azuma Y, Isogai E, Isogai H, Kawamura K 1994: Canine Lyme disease: clinical and serological evaluations in 21 dogs in Japan. Vet Rec 134: 369-72

Azuma Y, Kawamura K, Isogai H, Isogai E 1993: Neurologic abnormalities in two dogs suspected of Lyme disease. Microbiol Immunol 37: 325-329

Bagley RS 2003: Skills Laboratory, Part 1: How to obtain a CSF sample in dogs and cats. Vet Med US 98: 472-486

Bagley RS, Bohn AA 2003: Skills laboratory, Part 3: Clinical utility and interpretation of routine cerebrospinal fluid analysis. Vet Med US 98: 499-506

Baranton G 2002: Lyme Borreliosis in Human. In: Beugnet F et al. (Eds): Guide to Major Vector-borne Diseases of Pets. Merial, Lyon, pp. 167-175

Bateman H, Sigal L. 2000: Update on lyme carditis. Curr Infect Dis Rep 4: 299-301

Bhide M, Travnicek M, Curlik J, Stefancikova A 2004: The importance of dogs in eco-epidemiology of Lyme borreliosis: a review Vet Med - Czech 49: 135-142

Bohn AA, Bagley RS 2003: Skills laboratory, Part 2: CSF sample handling and examination. Vet Med US 98: $488-498$

Breitschwerdt EB, Nicholson WL, Kiehl AR, Steers CH, Meuten DJ, Levine JF 1994: Natural Infections with Borrelia Spirochetes in Two Dogs from Florida. J Clin Microbiol 32: 352-357

Burgess EC, Gentron-Fitzpatrick A and Wright WO 1987: Arthritis and systemic disease caused by Borrelia burgdorferi sensu latoinfection in cows. J Am Vet Med Assoc 191: 1468-1470

Cepelová J 2008: Lyme carditis: rare cause of dilated cardiomyopathy and rhythm disturbances. Vnitr Lek 54: 430-433

Cohen D, Heck FC, Heim B 1992: Seroprevalence of antibodies to Borrelia burgdorferi in a population of horses in central Texas. J Am Vet Med Assoc 201: 1030-1034

Derdáková M, Beati L, Pet'ko B, Stanko M, Fish D 2003: Genetic variability within Borrelia burgdorferi sensu lato genospecies established by PCR-single-strand conformation polymorphism analysis of the $\operatorname{rrfA}-\mathrm{rrlB}$ intergenic spacer in Ixodes ricinus ticks from the Czech Republic. Appl Environ Microbiol 69: 509-516

Egenvall A, Bonnett BN, Gunnarsson A, Hedhammar A, Shoukri M, Bornstein S, Artursson K 2000: Seroprevalence of granulocytic Ehrlichia spp. and Borrelia burgdorferi sensu lato in Swedish Dogs 1991-94. Scand J Infect Dis 32: 19-25

Gasser R, Lercher P, Klein W 1999: Lyme carditis and Borrelia-associated dilated cardiomyopathy. Heart Fail Rev 3: 241-248

Gerber B, Eichenberger S, Wittenbrink MM, Reusch CE 2007: Increased prevalence of Borrelia burgdorferi infections in Bernese Mountain Dogs: A possible breed predisposition. Vet Res 3: 15

Gern L, Estrada-Peña A, Frandsen F, Gray JS, Jaenson TG, Jongejan F, Kahl O, Korenberg E, Mehl R, Nuttall PA 1998: European reservoir hosts of Borrelia burgdorferi sensu lato. Zentralbl Bakteriol 287: 196-204

Giudice E, Domina F, Britti D, Di Pietro S, Pugliese A 2003: Clinical findings associated with Borrelia burgdorferi infection in the dog. Vet Res Commun. 27 (Suppl 1): 767-770

Goossens HAT, Bogaard AE van den, Nohlmans MKE 2001: Dogs as sentinels for human Lyme borreliosis in the Netherlands. J Clin Microbiol 39: 844-848

Grauer GF, Burgess EC, Cooley AJ, Hagee JH 1988: Renal lesion associated with Borrelia burgdorferi infection in a dog. J Am Vet Med Assoc 193: 237-239 
Greene CE and Straubinger RK 2006: Borreliosis. In: Greene CE (Ed): Infectious Diseases of the Dog and Cat. $3^{\text {rd }}$ edition. Saunders Elsevier. St. Louis, pp. 417-435

Greene RT, Walker RL, Nicholson WL and Levine JF 1991: Comparison of an enzyme-linked immunosorbent assay to an indirect immunofluorescence assay for the detection of antibodies to Borrelia burgdorferi in the dog. Vet Microbiol 26: 179-190

Higgins R 2004: Emerging or re-emerging bacterial zoonotic diseases: bartonellosis, leptospirosis, Lyme borreliosis, plaque. Rev Sci Tech Off Int Epiz 23: 569-581

Hovius KE 2002: Canine Borreliosis. In: Beugnet F et al. (Eds): Guide to Major Vector-borne Diseases of Pets. Merial, Lyon, pp. 167-175

Hovius KE 2005: Borreliosis. In: Shaw SE, Day MJ (Eds): Arthropod-borne Infectious Diseases of the Dog a Cat. Manson Publishing Ltd, London, pp. 100-109

Hovius KE, Beijer B, Rijpkema SGT, Bleumink-Pluym NMC, Houwers DJ 1999a: Identification of four Borrelia burgdorferi sensu lato species in Ixodes ricinus ticks collected from Dutch dogs. Vet Quart 21: 143-145

Hovius KE, Rijpkema SGT, Westers P, Zeist BAM van der, Asten FJAM van, Houwers DJ 1999b: A serological study of cohorts of young dogs, naturally exposed to Ixodes ricinus ticks, indicates seasonal reinfection by Borrelia burgdorferi sensu lato. Vet Quart 1999: 21: 16-20

Hovius KE, Stark LAM, Bleumink-Pluym NMC, Pol I van de, Verbeek-De Kruif N, Rijpkema SGT, Schouls LM and Houwers DJ 1999c: Presence and distribution of Borrelia burgdorferi sensu lato species in internal organs and skin of naturally infected symptomatic and asymptomatic dogs, as detected by polymerase chain reaction. Vet Quart 21: 54-58

Hulínská D, Votýpka J, Plch J, Vlček E, Valešová M, Bojar M, Hulínský V and Smetana K 2002: Molecular and microscopical evidence of Ehrlichia spp. and Borrelia burgdorferi sensu lato in patiens, animal nad tick in Czech Republic. Microbiologica 25: 437-448

Chang IF, Novosel V, Chang CF, Summers B, Ma DP, Chiang YW, Acree WM, Chu HJ, Shin S, Lein DH 2001: Experimental induction of chronic borreliosis in adult dogs exposed to Borrelia burgdorferi-infected ticks and treated with dexamethasone. Am J Vet Res 62: 1104-1112

Klimeš J, Juřicová Z, Literák I, Schánilec P, Trachta e Silva E 2001: Prevalence of antibodies to tickborne encephalitis and West Nile flaviviruses and the clinical signs of tickborne encephalitis in dogs in the Czech Republic. Vet Rec 148: 17-20

Kybicová K, Kurzová Z, Hulínská D 2008: Molecular and serological evidence of Borrelia burgdorferi sensu lato in wild rodents in the Czech Republic. Vector-Borne and Zoonotic Dis 2008: 8: 645-652

Kybicová K, Schánilec P, Hulínská D, Uherková L, Kurzová Z, Spejchalová S 2009: Detection of Anaplasma phagocytophilum and Borrelia burgdorferi sensu lato in dogs in the Czech Republic. Vector-Borne and Zoonotic Dis 9: 655-661

Levy SA, Dreesen DW 1992: Lyme borreliosis in dogs. Canine Practice 17: 5-14

Levy SA, Duray PH 1988: Complete heart block in a dog seropositive for Borrelia burgdorferi. Similarity to human Lyme carditis. J Vet Intern Med 2: 138-144

Levy SA, Magnarelli LA 1992: Relationship between development of antibodies to Borrelia burgdorferi in dogs and the subsequent development of limb joint borreliosis. J Am Vet Med Assoc 200: 344-347

Nagi KS, Joshi R, Thakur RK 1996: Cardiac manifestations of Lyme disease: a review. Can J Cardiol 12: 503-506

Nalmas S, Nagarakanti R, Slim J, Abter E, Bishburg E 2007: Electrocardiographic changes in infectious diseases. Hospital Physician 9: 15-27

Pejchalová K, Zákovská A, Fučík K, Schánilec P 2006: Serological confirmation of Borrelia burgdorferi infection in dogs in the Czech Republic. Vet Res Commun 30: 231-238

Piesman J, Gern L. Lyme borreliosis in Europe and North America. 2004: Parasitology 129: Suppl: S 191-220

Skotarczak B, Wodecka B 2003: Molecular evidence of the presence of Borrelia burgdorferi sensu lato in blood samples taken from dogs in Poland. Ann Agric Environ Med 10: 113-115

Skotarczak B, Wodecka B, Rymaszewska A, Sawczuk M, Maciejewska A, Adamska M, HermanowskaSzpakowicz T, Świerzbińska R 2005: Prevelance of DNA and antibodies to Borrelia burgdorferi sensu lato in dogs suspected of borreliosis. Ann Agric Environ Med 12: 199-205

Steere AC 2001: Lyme disease. N Engl J Med 345: 115-125

Straubinger RK 2000: PCR-Based quantification of Borrelia burgdorferi organisms in canine tissues over a 500day postinfection period. J Clin Microbiol 38: 2191-2199

Straubinger RK, Straubinger AF, Summers BA, Jacobson RH 2000: Status of Borrelia burgdorferi infection after antibiotic treatment and the effect of corticosteroids: an experimental study. J Infect Dis 181: 1069-1081

Straubinger RK, Summers BA, Chang YF, Appel MJG 1997: Persistence of Borrelia burgdorferi in experimentally infected dogs after antibiotic treatment. J Clin Microbiol 35: 111-116

Štefančíková A, Tresova G, Pet'ko B, Škardová I, Sesztáková E 1998: ELISA comparison of three whole-cell antigens of Borrelia burgdorferi sensu lato in serological study of dogs from area of Košice, eastern Slovakia. Ann Agric Environ Med 5: 25-30 
Plate XXII

Schánilec P. et al.: Clinical ... pp. 319-327

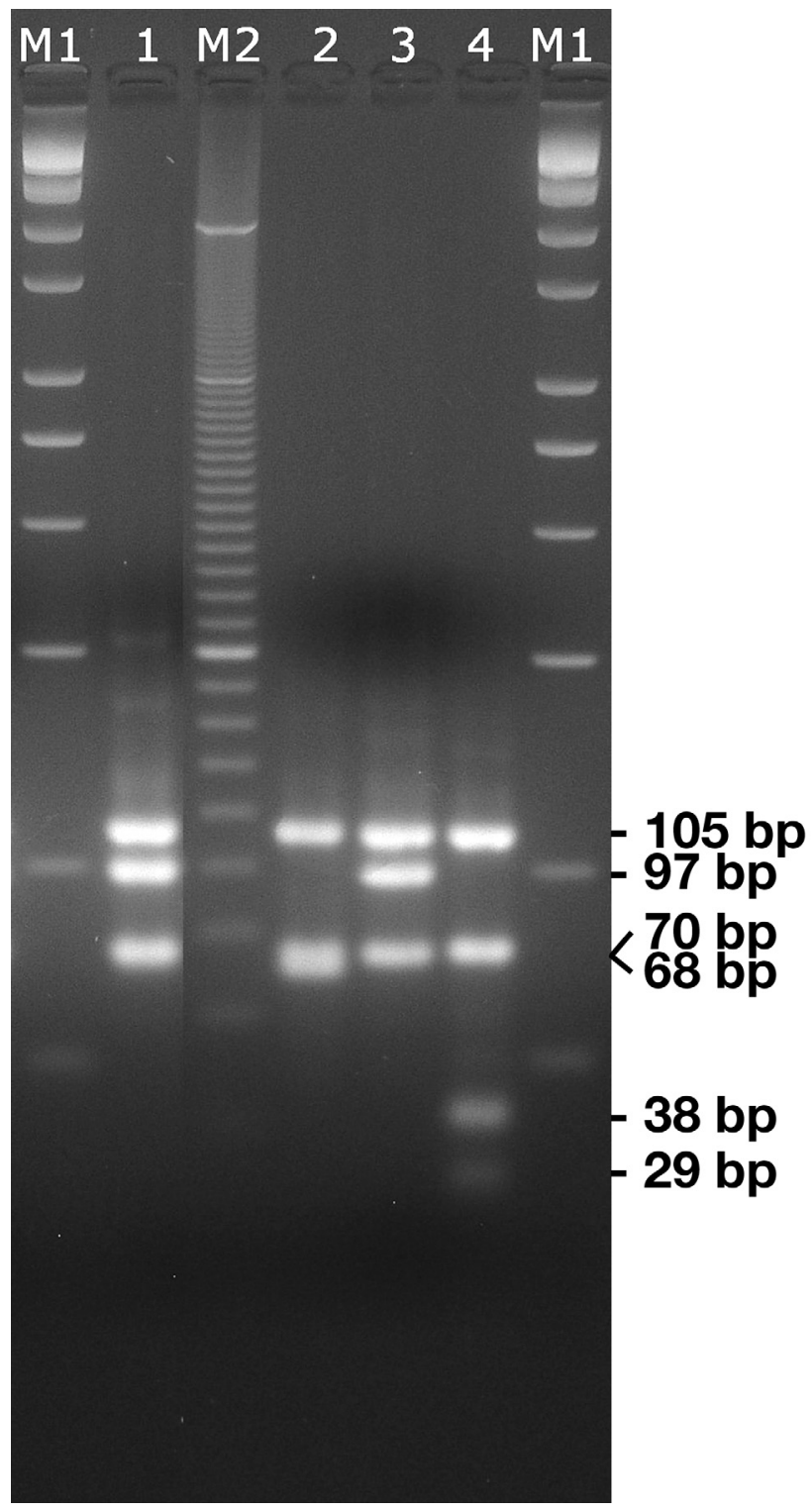

Fig. 1. RFLP profiles for the 5S-23S rDNA intergenic spacer of samples from the dog and positive controls. Lanes 2, 3, and 4 contain positive controls for B. afzelii, B. garinii, B. burgdorferi s. s., respectively. In lane 1 there is positive sample from dog Case 3 corresponding to $B$. garinii. Lanes M1 contain a Wide Range DNA Marker (Sigma) and lane M2 contains a PCR 20Bp Low Ladder Marker (Sigma). 